\title{
PREVALENSI TINGKAT KECEMASAN PADA PASIEN INFARK MIOKARD LAMA DI POLIKLINIK JANTUNG RSUP PROF. Dr. R.D. KANDOU
}

\author{
${ }^{1}$ I Ketut Maendra \\ ${ }^{2}$ Herdy Munayang \\ ${ }^{2}$ Anita E. Dundu \\ ${ }^{2}$ Neni Ekawardani
}

\author{
${ }^{1}$ Kandidat Skripsi Fakultas Kedokteran Universitas Sam Ratulangi Manado \\ ${ }^{2}$ Bagian Psikiatri Fakultas Kedokteran Universitas Sam Ratulangi \\ Email: Iketut_maendra@yahoo.com
}

\begin{abstract}
Lifestyle change affects the disease patterns from infection and malnutritions to degenerative diseases such as heart and vascular diseases. National prevalence of heart diseases in Indonesia is 7.2 percents and the prevalence in North Sulawesi is 8.2 percents. Myocardial infarction is usually followed by psychological reactions such as anxiety and depression. Anxiety has relation with heart disease progression and higher anxiety level increases the heart disease risk. This study aimed to know the prevalence of anxiety level in myocardial infarction patients at cardiac clinic of Prof. Dr. R. D. Kandou Hospital Manado. This was a descriptive study with sample size of 60 patients. The results showed that the prevalence of anxiety was $93.3 \%$ and the most common anxiety level was moderate anxiety.

Keywords: anxiety, myocardial infarction, prevalence
\end{abstract}

\begin{abstract}
Abstrak: Perubahan pola hidup mengubah pola penyakit mulai dari penyakit infeksi dan malnutrisi ke penyakit-penyakit degeneratif, salah satunya adalah penyakit jantung dan pembuluh darah. Prevalensi nasional penyakit jantung di Indonesia sebesar 7,2 persen sedangkan prevalensi di Sulawesi Utara adalah sebesar 8,2 persen. Infark miokard biasanya diikuti oleh reaksi-reaksi psikologis seperti depresi dan kecemasan. Penelitian ini bertujuan untuk mengetahui prevalensi tingkat kecemasan pada pasien infark miokard lama di poliklinik jantung RSUP Prof. Dr. R. D. Kandou Manado. Penelitian ini merupakan penelitian deskriptif dengan sampel yang berjumlah 60 orang. Hasil penelitian menunjukkan prevalensi kecemasan pada pasien infark miokard di poliklinik jantung RSUP Prof. Dr. R. D. Kandou Manado yaitu 93,3\% dan tingkat kecemasan sedang didapatkan paling banyak.
\end{abstract}

Kata kunci: kecemasan, infark miokard, prevalensi

Perubahan pola hidup merupakan salah satu dampak dari kemajuan ekonomi di seluruh dunia termasuk Indonesia. Akibat dari perubahan pola hidup, maka terjadi perubahan pola penyakit mulai dari penyakit infeksi dan malnutrisi ke penyakit-penyakit degeneratif, salah satunya adalah penyakit jantung dan pembuluh darah. ${ }^{1}$ Menurut Riset Kesehatan Dasar (RISKESDAS) 2007, Indonesia telah mengalami perubahan pola penyakit dari penyakit menular menjadi penyakit tidak menular (strok, diabetes melitus, hipertensi, penyakit jantung iskemik). ${ }^{2}$

Prevalensi nasional penyakit jantung di Indonesia sebesar 7,2\% (berdasarkan diagnosis tenaga kesehatan dan gejala) sedangkan prevalensi di Sulawesi Utara adalah sebesar 8,2\%. Angka ini lebih tinggi dari prevalensi nasional. Hal ini menunjukkan bahwa penyakit jantung 
merupakan salah satu masalah kesehatan di Sulawesi Utara. ${ }^{2,3}$ Sebanyak 9,3\% kematian di Indonesia disebabkan oleh penyakit jantung iskemik. ${ }^{2}$

Infark miokard merupakan penyakit jantung iskemik yang sering ditemukan dalam kehidupan sehari-hari. Infark miokard akut didefinisikan sebagai nekrosis ireversibel jaringan otot jantung yang disebabkan oleh alirah darah yang inadekuat dalam periode tertentu. ${ }^{3}$

Infark miokard biasanya diikuti oleh reaksi-reaksi psikologis seperti depresi dan kecemasan. Kecemasan pada pasien infark miokard masih kurang mendapat perhatian meskipun prevalensinya cenderung lebih tinggi daripada depresi. Kecemasan pada pasien infark miokard tidak bisa dianggap sepele karena beberapa penelitian menunjukkan jumlah yang signifikan pada pasien infark miokard yang mengalami kecemasan persisten dan tidak kunjung sembuh. ${ }^{4}$

Pada pasien dengan infark miokard akut, prevalensi peningkatan gejala kecemasan rata-rata sebesar $30 \%$. Sebuah meta-analisis dari 12 studi oleh Roest (2012) yang mencakup 5750 pasien dengan infark miokard menunjukkan bahwa kecemasan meningkatkan risiko sebesar 36\% akan terjadinya peristiwa kardiovaskular atau mortalitas. ${ }^{5}$ Benninghoven (2006) melakukan penelitian pengaruh kecemasan pada pasien infark miokard terhadap perjalanan penyakit jantung, hasil penelitian didapatkan bahwa pasien dengan tingkat kecemasan yang lebih parah meningkatkan resiko kejadian penyakit jantung lainnya dibandingkan mereka yang tingkat kecemasannya lebih rendah. ${ }^{6}$

\section{METODE PENELITIAN}

Penelitian ini bersifat deskriptif dan menggunakan rancangan potong lintang yang dilakukan di poliklinik jantung RSUP Prof. Dr. R. D. Kandou Manado pada bulan November 2013-Maret 2014. Kriteria inklusi yaitu pasien infark miokard lama pada poliklinik jantung RSUP. Prof. Dr. R. D. Kandou Manado.

\section{HASIL PENELITIAN}

Pada penelitian yang dilakukan pada bulan November 2013 hingga Maret 2014 didapatkan sampel sebanyak 60 orang yang melakukan pemeriksaan di poliklinik jantung RSUP Prof. Dr. R. D. Kandou Manado, sampel telah menyetujui dan mengisi pengisian kuesioner penelitian yang diberikan peneliti.

Pada Tabel 1 didapatkan informasi mengenai distribusi sampel menurut jenis kelamin dimana didapatkan 45 sampel laki-laki (75\%) dan 15 sampel perempuan $(25 \%)$.

Tabel 1. Distribusi Sampel Berdasarkan Jenis Kelamin

\begin{tabular}{lll}
\hline Jenis Kelamin & Frekuensi & \% \\
\hline Laki-laki & 45 & 75,0 \\
Perempuan & 15 & 25,0 \\
\hline Total & 60 & 100,0 \\
\hline
\end{tabular}

Tabel 2 menunjukkan distribusi sampel berdasarkan kelompok umur. Pada kelompok umur 45-55 tahun berjumlah 10 orang (16,7\%), 56-65 tahun berjumlah 19 orang $(31,7 \%), 66-75$ tahun berjumlah 20 orang $(33,3 \%),>75$ tahun berjumlah 11 orang $(18,3 \%)$.

Tabel 2. Distribusi Sampel Berdasarkan Kelompok Umur

\begin{tabular}{ccc}
\hline $\begin{array}{c}\text { Kelompok } \\
\text { Umur }\end{array}$ & Frekuensi & \% \\
\hline $\mathbf{4 5 - 5 5}$ & 10 & 16,7 \\
$\mathbf{5 6 - 6 5}$ & 19 & 31,7 \\
$\mathbf{6 6 - 7 5}$ & 20 & 33,3 \\
$\mathbf{> 7 5}$ & 11 & 18,3 \\
\hline Total & 60 & 100,0 \\
\hline
\end{tabular}

Mengacu pada Tabel 3 dapat dilihat bahwa terbagi 2 kelompok yaitu bekerja 
dan tidak bekerja. Jumlah sampel yang masih bekerja adalah 20 orang $(33,3 \%)$ dan yang sudah tidak bekerja 40 orang $(66,7 \%)$

Tabel 3. Distribusi Sampel Berdasarkan Pekerjaan

\begin{tabular}{ccc}
\hline Pekerjaan & Frekuensi & $\boldsymbol{\%}$ \\
\hline Bekerja & 20 & 33,3 \\
Tidak Bekerja & 40 & 66,7 \\
\hline Total & 60 & 100,0 \\
\hline
\end{tabular}

Berdasarkan Tabel 4 Jumlah sampel dengan pendidikan terakhir SD sebanyak 4 orang $(6,7 \%)$, SMP sebanyak 9 orang (15\%), SMA/SMK sebanyak 31 orang $(51,7 \%)$, Diploma sebanyak 4 orang $(6,7 \%)$, dan Sarjana sebanyak 12 orang $(20 \%)$.

Tabel 4. Distribusi Sampel Berdasarkan Pendidikan Terakhir

\begin{tabular}{lll}
\hline Pendidikan Terakhir & Frekuensi & \% \\
\hline SD & 4 & 6,7 \\
SMP & 9 & 15,0 \\
SMA/SMK & 31 & 51,7 \\
Diploma & 4 & 6,7 \\
Sarjana & 12 & 20,0 \\
\hline Total & 60 & 100,0 \\
\hline
\end{tabular}

Tabel 5 memerlihatkan tingkat kecemasan dari 60 sampel yang diteliti. Dari 4 sampel yang mengisi kuesioner tidak ditemukan kecemasan, kecemasan ringan sebanyak 26 orang $(43,3 \%)$, kecemasan sedang sebanyak 29 orang $(48,3 \%)$, dan kecemasan berat sebanyak 1 orang $(1,7 \%)$ sehingga diperoleh $6,7 \%$ tidak mengalami kecemasan dan 93,3\% mengalami kecemasan.
Tabel 5. Distribusi Sampel Berdasarkan Tingkat Kecemasan

\begin{tabular}{lll}
\hline Tingkat Kecemasan & Frekuensi & \% \\
\hline Tidak ada kecemasan & 4 & 6,7 \\
Kecemasan ringan & 26 & 43,3 \\
Kecemasan sedang & 29 & 48,3 \\
Kecemasan berat & 1 & 1,7 \\
\hline Total & 60 & 100,0 \\
\hline
\end{tabular}

Tabel 6 memberikan informasi berupa distribusi sampel berdasarkan tingkat kecemasan menurut jenis kelamin dimana pada jenis kelamin laki-laki tingkat kecemasan tertinggi yaitu kecemasan sedang yaitu sebanyak 23 orang $(51,1 \%)$ dan pada jenis kelamin perempuan paling tinggi yaitu kecemasan ringan 8 orang $(53,3 \%)$.

Tabel 6. Distribusi Sampel Berdasarkan Tingkat Kecemasan Menurut Jenis Kelamin

\begin{tabular}{|c|c|c|c|c|}
\hline \multirow{3}{*}{$\begin{array}{l}\text { Tingkat } \\
\text { Kecemasan }\end{array}$} & \multicolumn{4}{|c|}{ Jenis Kelamin } \\
\hline & \multicolumn{2}{|c|}{ Laki-laki } & \multicolumn{2}{|c|}{ Perempuan } \\
\hline & $\mathrm{N}$ & $\%$ & $\mathrm{~N}$ & $\%$ \\
\hline $\begin{array}{ll}\text { Tidak } & \text { ada } \\
\text { kecemasan }\end{array}$ & 4 & 8,9 & 0 & 0,0 \\
\hline $\begin{array}{l}\text { Kecemasan } \\
\text { ringan }\end{array}$ & 18 & 40,0 & 8 & 53,3 \\
\hline $\begin{array}{l}\text { Kecemasan } \\
\text { sedang }\end{array}$ & 23 & 51,1 & 6 & 40,0 \\
\hline Kecemasan berat & 0 & 0,0 & 1 & 6,7 \\
\hline Total & 45 & 100,0 & 15 & 100,0 \\
\hline
\end{tabular}

Tabel 7 memberi informasi mengenai tingkat kecemasan menurut kelompok umur dimana pada kelompok umur 45-55 tahun tertinggi yaitu kecemasan sedang, pada kelompok umur 56-65 tahun tertinggi yaitu kecemasan ringan, dan pada kelompok umur $>75$ tahun tertinggi yaitu kecemasan sedang. 
Maendra, Munayang, Dundu, Ekawardani: Prevalensi Tingkat Kecemasan...

Tabel 7. Distribusi Sampel Berdasarkan Tingkat Kecemasan Menurut Kelompok Umur

\begin{tabular}{lllll}
\hline \multirow{2}{*}{ Tingkat Kecemasan } & \multicolumn{4}{c}{ Kelompok Umur } \\
\cline { 2 - 5 } & $45-55$ & $56-65$ & $66-75$ & $>75$ \\
\hline Tidak ada kecemasan & 0 & 1 & 2 & 1 \\
Kecemasan ringan & 4 & 11 & 8 & 3 \\
Kecemasan sedang & 6 & 6 & 10 & 7 \\
Kecemasan berat & 0 & 1 & 0 & 0 \\
\hline Total & 10 & 19 & 20 & 11 \\
\hline
\end{tabular}

Tabel 8 memperlihatkan tingkat kecemasan berdasarkan tingkat pendidikan. Pada tingkat pendidikan SD paling tinggi pada kecemasan sedang, SMP paling tinggi kecemasan sedang, SMA/SMK tertinggi tingkat kecemasan ringan, tingkat pendidikan diploma tertinggi juga kecemasan ringan dan pada tingkat pendidikan sarjana paling tinggi kecemasan ringan.

Tabel 8. Distribusi Sampel Berdasarkan Tingkat Kecemasan Menurut Tingkat Pendidikan

\begin{tabular}{llllll}
\hline \multirow{2}{*}{ Tingkat Kecemasan } & \multicolumn{5}{c}{ Tingkat Pendidikan } \\
\cline { 2 - 6 } & SD & SMP & SMA/SMK & Diploma & Sarjana \\
\hline Tidak ada kecemasan & 0 & 0 & 2 & 1 & 1 \\
Kecemasan ringan & 1 & 2 & 15 & 2 & 6 \\
Kecemasan sedang & 2 & 7 & 14 & 1 & 5 \\
Kecemasan berat & 1 & 0 & 0 & 0 & 0 \\
\hline Total & 4 & 9 & 31 & 4 & 12 \\
\hline
\end{tabular}

\section{BAHASAN}

Kecemasan sering terjadi pada pasien dengan sindrom koroner akut maupun penyakit kardiovaskuler lainnya. Meskipun prevalensinya cukup tinggi, kedua kondisi psikiatrik ini sering tidak disadari oleh petugas kesehatan dan tidak mendapatkan penanganan selama berbulan-bulan hingga bertahun-tahun. Hal ini tentu dapat berpengaruh terhadap kualitas hidup pasien. $^{7}$

Pasien penyakit jantung dan pembuluh darah sering merasa cemas, ketakutan dan depresi. Hampir semua pasien menyadari bahwa jantung adalah organ yang penting dan ketika jantung mulai rusak maka kesehatan juga terancam. Ketika penyakitnya meningkat dan manifestasinya memburuk, pasien sering memiliki ketakutan yang berlebihan akan cacat permanen dan kematian. Para pasien mengekspresikan ketakutan dengan berbagai cara seperti mimpi buruk, insomnia, kecemasan akut, depresi dan memungkiri kenyataan. ${ }^{8}$

Selain itu, peningkatan level cemas yang dilaporkan sendiri mencapai 20\%$50 \%$ pada pasien dengan infark miokard akut, dengan seperempatnya mengalami gejala cemas yang sama dengan yang dialami pasien di unit psikiatri. ${ }^{9}$

Penelitian ini bertujuan untuk mendapatkan data tentang prevalensi dan tingkat kecemasan pada pasien infark miokard lama di poliklinik jantung RSUP Prof. Dr. R. D. Kandou periode November-Desember 2013 berdasarkan umur, jenis kelamin, kelompok umur, dan tingkat pendidikan.

Pada penelitian ini didapatkan sampel sebanyak 60 pasien dengan infark miokard yang terdiri dari 45 laki-laki dan 
15 perempuan. Berdasarkan perbedaan kecemasan pada laki-laki dan perempuan pada tabel 6 didapatkan bahwa dari 45 sampel laki-laki ditemukan sebanyak 41 pasien $(91,9 \%)$ mengalami kecemasan dengan variasi tingkat kecemasan dan 4 pasien $(8,9 \%)$ tidak mengalami kecemasan, pada sampel perempuan didapatkan semua atau 15 pasien $(100 \%)$ mengalami kecemasan dengan variasi kecemasan yang berbeda. Penelitian ini sesuai dengan temuan yang didapatkan oleh Kim (2000) yang menjabarkan bahwa perempuan dengan infark miokard yang mengalami kecemasan lebih banyak dibandingkan laki-laki, hal ini dapat dijelaskan secara parsial oleh sebab status pernikahan dan penghasilan yang rendah pada saat terkena infark miokard. Berdasarkan penelitian Kim, faktor-faktor yang cenderung mempengaruhi perbedaan kecemasan perempuan dan laki-laki adalah faktor sosiodemografis seperti umur, status pernikahan, perawatan diri, aktivitas sosial dimana pada beberapa faktor tersebut perempuan diduga lebih rentan, namun hal ini masih memerlukan penelitian lebih lanjut. ${ }^{8}$

Pada Tabel 7, hasil penelitian didapatkan berupa kecemasan menurut kelompok umur. Pada kelompok umur 4555 didapatkan 10 orang (100\%) yang mengalami kecemasan, pada kelompok umur 56-65 tahun ditemukan 18 orang $(94,8 \%)$ yang mengalami kecemasan, pada kelompok umur 66-75 terdapat 18 orang $(90 \%)$ yang mengalami kecemasan, sedangkan pada kelompok umur >75 tahun didapatkan 11 orang $(90,9 \%)$ yang mengalami kecemasan. Berdasarkan penelitian Roest (2010) didapatkan rentang umur yang mengalami kecemasan pada penderita infark miokard yaitu 38-72 tahun. Penelitian yang dilakukan oleh Roest pada tahun 2012 didapatkan bahwa usia menjadi prediktor signifikan kecemasan pada pasien infark miokard, namun penjelasan pengaruh usia terhadap kecemasan pada pasien infark miokard perlu diteliti lebih mendalam lagi. ${ }^{5,10}$

Pada tabel 8 berisi informasi tingkat kecemasan menurut tingkat pendidikan. Pada tingkat pendidikan SD terdapat 4 orang $(100 \%)$ yang mengalami kecemasan, SMP sebanyak 9 orang (100\%) yang mengalami kecemasan, SMA/SMK sebanyak 29 orang $(93,6 \%)$, Diploma sebanyak 3 orang $(75 \%)$ dan tingkat pendidikan sarjana sebanyak 11 orang $(91,7 \%)$. Berdasarkan penelitian Roest tahun 2012 didapatkan bahwa tingkat pendidikan tidak memiliki pengaruh yang signifikan pada tingkat kecemasan pada pasien yang menderita infark miokard. ${ }^{5}$

Menurut beberapa studi belum ditemukan hubungan dan mekanisme yang pasti antara kecemasan dengan infark miokard, namun kecemasan hingga saat ini masih diduga erat kaitannya sebagai faktor prognostik dan faktor resiko untuk kejadian penyakit jantung. Kecemasan pada pasien infark miokard memerlukan penanganan secara holistik dan harus mendapatkan perhatian lebih dari petugas medis dan memerlukan penanganan holistik. Penanganan secara holistik sangat perlu terhadap penyakit infark miokard termasuk juga terhadap kondisi kejiwaan pasien.. ${ }^{4,6,10}$

Kemungkinan persistensi kecemasan terhadap pasien infark miokard harus mendapatkan perhatian sehingga pentingnya pemeriksaan fisik dan psikiatri serta follow-up yang berkesinambungan terhadap pasien infark dapat membantu pasien dalam mempertahankan kondisi seoptimal mungkin sehingga dapat terhindar dari resiko-resiko kejadian penyakit jantung lanjutan. 5,11

\section{SIMPULAN}

Dari penelitian ini dapat disimpulkan bahwa prevalensi kecemasan pada pasien infark miokard di Poliklinik Jantung RSUP Prof. Dr. R. D. Kandou Manado periode November -Desember 2013 yaitu 93,3\%. Tingkat kecemasan pada pasien infark miokard yaitu tidak ada kecemasan (6,7\%), kecemasan ringan (43,3\%), kecemasan sedang $(48,3 \%)$, dan kecemasan berat $(1,7 \%)$. Prevalensi 
kecemasan tertinggi pada kelompok umur 56-65 dan 66-75 tahun dan terendah pada kelompok umur 45-55 tahun. Prevalensi kecemasan tertinggi pada kelompok dengan tingkat pendidikan SMA/SMK dan terendah pada tingkat pendidikan Diploma.

\section{DAFTAR PUSTAKA}

1. Supriyono M. Faktor-faktor yang Berpengaruh Terhadap Kejadian Infark Miokard Pada Kelompok Usia $\leq 45$ Tahun [Tesis]. Semarang: Universitas Diponegoro, 2000.

2. Badan Penelitian dan Pengembangan Kesehatan Kementerian Kesehatan Republik Indonesia. Riset Kesehatan Dasar (Riskesdas) Jakarta, 2007.

3. Kyungeh A. Anxiety after Acute Myocardial Infarction and In-Hospital Complications. Journal of Korean Academy of Nursing. 2002;32(7):9991008.

4. Ratcliffe D, MacLeod A, Sensky T. Anxiety in Patients Who Have Had a Myocardial Infarction: The Maintaining Role of Perceived Physical Sensations and Causal Attributions. British Association for Behavioral and Cognitive Psychotherapies. 2006;34:201-17.

5. Roest AM, Zuidersma M, de Jonge $P$. Myocardial Infarction and Generalised Anxiety Disorder: 10year Follow-Up. The British Journal of Psychiatry. 2012;200:324-9.

6. Benninghoven D, Kaduk A, Wiegand U, Specht T, Kunzendorf S, Jantschek G. Influence of Anxiety on the Course of Heart Disease after Acute Myocardial Infarction: Risk Factor or Protective Function? Psychotherapy and Psychosomatics. 2006;75:56-61.

7. Jeff CH, Christopher MC, James LJ. The relationship between depression, anxiety, and cardiovascular outcomes in patients with acute coronary syndromes. Neuropsychiatric Disease and Treatment. 2010;6:123-36.

8. Kim KA, Moser DK, Garvin BJ, Riegel BJ, et al. Difference Between Men and Women in Anxiety Early After Acute Myocardial Infarction. American Journal of Critical Care. 2000 July;9(4):245-53.

9. Black JM, Hawks JK. Medical Surgical Nursing: Clinical Management for Positive Outcomes (7th Ed). Philadephia: Elsevier, 2005.

10. Roest AM, Martens EJ, de Jonge P, Denollet J. Anxiety and Risk of Incident Coronary Heart Disease. Journal of the American College of Cardiology. 2010;56(1):38-46.

11. Lane D, Caroll D, Ring C, Beevers DG, Lip GYH. The Prevalence and Persistence of Depression and Anxiety Following Myocardial Infarction. British Journal of Health Psychology. 2002;7:11-21. 